\title{
VII. Extract of a letter from Dr. Sam. L. Mitchill, Professor of Chemistry in Columbia College, to Mr. Tilloch
}

\section{Sam.L. Mitchill}

To cite this article: Sam.L. Mitchill (1801) VII. Extract of a letter from Dr. Sam. L. Mitchill, Professor of Chemistry in Columbia College, to Mr. Tilloch , Philosophical Magazine Series 1, 8:32, 326-328, DOI: $10.1080 / 14786440108562652$

To link to this article: http://dx.doi.org/10.1080/14786440108562652

曲 Published online: 25 Jan 2010.

Submit your article to this journal $\pi$

ЏII Article views: 2

Q View related articles $₫$ 
further from each other. The blow-pipes $b, i$, alfo turn at $k, l$, in the tubes $f, g$, to enable the operator to alter the direction of the ftreams, and make them fall on the charcoal $m$, at any angle he pleafes. The double blow-pipe juf defcribed was that employed in all the experiments, from the 8 th to the 3 if inclufive.

VII. Extraet of a Letter from Dr. Sam. L. MitchilL,

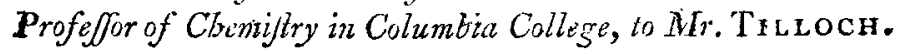
SIR; Ncw-York, Dec. 3, 1800.

........ ConsIderING all things, I really truft that the weftern world is doing its part in the philofophical work of the day. We have great and cxcellent opportunities of obferving phænomena here, and fome among us are difigent to let no opportunity be bolt. The following points we think fully eftablifhed:

I. There is proof as pointed as it needs to be, that the fickly feafons which affict our cities are accoinpanied with, and occafioned by, noxious exhalations, locally produced either on board fea-veffets, or in ftores, cellars, divellinghoufes, and finks, in our towns.

2. When exilting in flips, thefe noxious productions are not received on board in the ports of the Weft Indies, or other places beyond fea, as is vulgarly believed, but univerfally are produced within the fides of the veffel itfelf, from naftinefs and corruption there.

3. Not only are the exhalations from ur corrupting $f f B$, beef, and bides, and from our abominable prioy-pits, very injurious to health, and deftructive of life, but thefe very vapours are fo aid as to be fmelled and tafted by the repackers of provifions.

4. In the alimentary canal of fuch perfons as feed upon beef and fifh, and, generally fpeaking, of leun animal fubflance, there is formed a fimilar acid, whofe prefence has been detected, and of a ftrength fufficient to curdle milk, to excoriate the fundament, and to effervefce with carbonats of alkaline falts. 
5. The fame acid product, or fome modification of it, shich, when volatilifed and fpread through the atmofphere, produces our endemic fevers (for our annual diftempers are not epidemics), of the various grades from intermittent to yellow and peflilential, does, when engendered in the inteftinal canal, ftir up dyfentery and its concomitant fymptoms.

6. The excellency of alkalime remedies, efpecially the neutral falts, in which foda is combined with a weak acid, evinces the exiftence of an inflaming and corroding fournefs, which being overcome either by alkalies per os or per anum, gives the patient great and fpeedy relief.

7. The application of the fame mode of reafoning to the buman mouth, which has becm employed with refpect to the ftomach and bowels, will explain the generation and noxious effect of a fimilar acid among the textb and around the gums, of their corrofion and deffruction by it, and of the utility and importance of alkalies as dentifrices and fweeteners of the mouth.

8. An explanation is, on the fame principles, given to the manner in which buman garments grow foul and peftilintial, the excretions lodged in them degenerating to acidity by expofure to the air, and thus becoming fomites of infection. This infection never poffefing any /pecific quality, but merely being the acid ofispring of common putrefaction. And on this depends the theory of alkalies, and lys and joaps, in defroying infection if prefent, or in preventing its formation, and their wholefome and purifying power in wafhing, fcouring, and houfekeeping.

9. Experiments lately made in the New-York hafpital have proved to me that foul and ill-conditioned ulcors, efpecially of the fiphylitic kind, contain an acid fo confiderable as in three or four bours to turn litmus-paper red. I have found alkatine remedies of admirable ufe in fuch furgical cafes locally applied. We are thus poffeffed of a clue to explain much of the nature of corrading maliguant and inficlious ulceration; of the manner of Jicping it by alkalies; and of the explanation of bectis fever from an abforption of this acid virus.

10. It is rendered plain of what materials cities ought to 
be built and paved to be mot healthy, to wit, the calcareous; and that a wife policy thould introduce marble and limeftone into general ufe.

II. The ufe of pit-coal for fucl has an additional recommendation. During combution it affords much ammoniac; and this volatile alkali is capable of neutralifing abundance of feptic acid. Commonly, where the burning of coal is general, peftilential diftempers are more rare than they ufe to be. But my paper fails me before I have finithed my enumeration : I muft therefore conclude, and leave the reft for a future communication, though not without affuring you that I remain yours, with nuch regard and refpect,

To A. Tilloch, Efq.

SAM. L. MITCHILL.

VIII. Extralt of a Letter from Profeffor ABILDGAARD, Secretary to the Royal Society at Copinbagen, to C. HuzarD, Member of the French National Inftitute, on the Quantity of Carbon in the Blood*.

I SHALL give you the refult of fome experiments which I made and repeated to difcover the quantity of carbon that exilts in the blood, and which gave me leis of that fubftance in the arterial than in the venous blood.

Ift, A hundred parts of the venous blood of a horfe, when dried in a moderate heat, gave 26 parts of a fubftance fo dry that it could be pulverifed.

2,d, A hundred parts of arterial blood of the fame horfe gave 25 parts of dry fubftance.

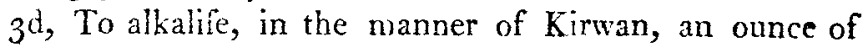
nitie by detonation (the ounce being 480 grains), required 192 grains of venous blood, and only 160 of arterial.

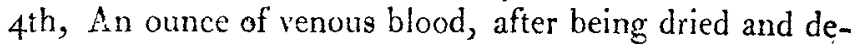
compofed in a clofe veffel, yiclded $15 \%$ grains of charcoal.

$5^{\text {th }}$, The fame quantity of arterial blood gave only $87 \frac{x}{2}$ grains of charcóal.

6 th, To decompofe 480 grains of nitre, required 148 grains

* From the Annales de Cbimie, No. 106. 